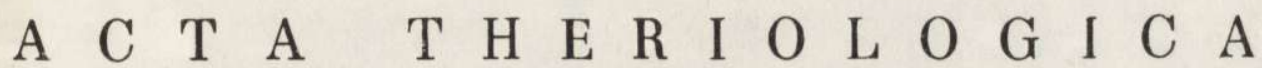 \\ VOL. XIV, 17: 229-246. \\ BIAŁOWIEŻA \\ 30.VIII.1969
}

\author{
Roman J U S I A K
}

\section{Metabolic Rate of Tissue Slices of Rats and Rabbits as Aifected by Age and Body Size}

\author{
[With 2 Figs. \& 5 Tables]
}

\begin{abstract}
The studies were carried out by the Warburg technique and the obtained results corrected after establishing by the method of $\mathrm{Ca}$ s ca$\mathrm{r}$ a no et al. what part of the incubated slices participates in the respiration. Most of the studied tissues from small animals showed higher metabolic rate than the homologous tissues derived from large animals, but the difference was less pronounced than that between basal metabolic rates. The estimated sum of tissue metabolism in young rats approached $100 \%$ of their basal metabolic rate, but in the case of adult rats this figure amounted only to $70 \%$. These results indicate that the metabolism of tissues in vitro is markedly different from their metabolism in vivo. In the author's opinion the main reason for this discrepancy lies in the fast disappearance of the effect of central regulating systems (nervous and humoral) on the metabolic processes occurring in cells of the isolated tissues.
\end{abstract}

\section{INTRODUCTION}

The relationship between the basal metabolic rate of adult homoiothermic animals and their body size may be described by the empirically established equation:

$$
M=k W^{3 / 4} \text {. . . . . . . }
$$

where $M=$ basal metabolism rate, $W=$ body weight in kilograms, $k=$ proportionality coefficient representing the level of metabolism of a particular group of animals (K le i b e r, 1947, 1961).

When the basal metabolic rate is computed per unit of body weight, instead of the total weight of an animal, the described relationship will appear under the form of another equation:

$$
M=k W^{-1 / 4} \text {. . . . . . . . }
$$

where the meaning of symbols is the same as given above.

This equation (2) indicates that the basal metabolic rate expressed per unit of body weight is higher in smaller animals. Since the metabolism of the whole animal is doubtless the sum of metabolism of its tissues, the course of metabolic processes in tissues in situ of smaller animals must be faster than in 
larger ones. In studies on the tissue metabolism in vitro $\mathrm{Terroine} \& \mathrm{Roche}$ (1925) did not confirm this relationship. These authors claimed that homologous tissues of various animals respirate in vitro with equal intensity and their distinctness in vivo results from the regulating systems of the whole animal organism. Grafe (1925) reported, moreover, that the tissue metabolism in vitro is more intensive than in vivo. More recent studies of arious authors (B e r t a la $\mathrm{nf}$ fy \& Pirozynski, 1951, 1953; Bertalanffy \& Estwick, 1953; Crandall \& Smith, 1952; Kleiber, 1941; Krebs, 1950; Schmidt-Nielsen, 1951) showed, however, that also in vitro some tissues isolated from small animals more intensive than in vivo. More recent studies of various authors (B e r t a la $\mathrm{n} f-$ respirate more intensively than those from large ones. This relationship is equally visible when comparing the metabolism of tissues from various animal species and from specimens differing in weight but belonging to the same species. Hence there is some similarity between the tissue metabolism in vitro and in vivo, although the parallel is not complete. The interdependence between the basal metabolic rate and body size remained in a good agreement with equation (2) only in the case of the liver tissue (Kle i ber, 1941; K rebs, 1950). With other tissues the slope of the curve illustrating this relationship is considerably smaller. As an example, in the muscle tissue the exponent in equation (2) amounts to -0.1 instead of -0.25 (B e r talanffy \& E s twick, 1953).

Results reported by various authors differ in the quantative respect, sometimes considerably. Due to these differences the summated tissue metabolism varied between $66 \%$ (F ield et al., 1939) and $101 \%$ ( $\mathrm{H} \mathrm{ust}$ on \& Martin, 1954) of the whole animal basal metabolism. Discrepancies in results obtained by various authors might he related to different methods of estimation, especially in respect of the composition of incubation medium and in the thickness of tissue slices. Similarly prepared slices of the same tissue consume various amounts of oxygen during the incubation in different media. The problem of selection of the proper incubation medium was studied by $\mathrm{Krebs}(1950)$ and since that time his medium III is most commonly used because it is assumed that the intensity of oxygen uptake by tissue slices in these conditions is very close to the tissue respiration in situ.

When the prepared slices are too thick oxygen cannot penetrate to their central parts due to the slowness of diffusion. Warburg proposed a formula allowing the calculation to be made of the maximum slice thickness when all the cells are still sufficiently provided with oxygen. The Warburg's formula and methods of its application are described in a manual of manometric techniques ( $\mathrm{U} \mathrm{mb}$ r e it et al., 1957). It is possible to calculate from this formula that if the gas phase in the Warburg flask contains pure oxygen the maximum thickness of slices may amount to $0.5 \mathrm{~mm}$. Hence as a rule it is assumed that slices not thicker than $0.5 \mathrm{~mm}$ participate as a whole in the respiration. Huston \& M a rtin (1954) observed, however, that slices placed in the Warburg flask on a special padding made of fiber glass utilized more oxygen than the alike slices studied by the standard technique. These authors explained the observed phenomenon by better penetration of oxygen in the modified method. This might mean that in the standard technique not all cells are provided with oxygen and participate in respiration. Thus a conclusion arises that computation of results on the total mass of studied slices may lead to quantitatively erroneus results. The possibility of correction of results is provided by a technique employed by C a s c a r a no et al. $(1959,1961$, 1964). These authors found that tetrazolium salts, among which the best one is 
denoted as INT (2-p-iodophenyl-3-p-nitrophenyl-5-phenyl tetrazolium chloride), penetrate the tissue and during incubation in the atmosphere of pure nitrogen are reduced during metabolic processes. The reduced products, formazans, are strongly coloured and hence easily detected under microscope in any part of the studied slice. Ca s c a r a no et al. $(1959,1961,1964)$ hold an opinion that the depth of penetration of tetrazolium salts into tissue slices in the described conditions corresponds to the depth of oxygen penetration. Althoug they do not supply the biochemical or physical argumentation for this conclusion various facts confirm its correctness. The facts indicate that some factors influencing the oxygen penetration into tissues exert the identical effect on the depth of penetration of INT. By measuring the penetration of tetrazolium salts in the tissue it is possible, therefore, to estimate what part of the studied slices participate in the metabolism. Owing to this method more accurate results may be obtained. In the present study it was decided to utilize this technical refinement and reinvestigate the widely discussed problem of the dependance of tissue metabolism from the age and body size of animals. It was hoped that the corrected results will remove ambiguities associated with this problem.

\section{MATERIAL AND METHODS}

The experiments were carried out on male rats (Wistar) and rabbits (outbred). In each species the animals were divided into two groups differing in the age and body size. Table 1 gives a detailed number of animals in each group as well as their age and mean weight.

Table 1.

Number of animals in the experimental groups, their age and mean body weight.

\begin{tabular}{|c|c|r|r|}
\hline Group & No. of animals & Age days & $\begin{array}{r}\text { Body weight } \\
\text { g mean } \pm \text { S.E. }\end{array}$ \\
\hline I young rats & 10 & $6-11$ & $16.5 \pm 1.1$ \\
II adult rats & 34 & $35-90$ & $210.7 \pm 17.1$ \\
III young rabbits & 10 & $6-15$ & $127.2 \pm 13.6$ \\
IV adult rabbits & 10 & $240-300$ & $2397.0 \pm 51.6$ \\
\hline
\end{tabular}

The animals were reared in thermoneutral environment and fed ad libitum. They were killed by decapitation after stunning by a strong strike in the head. Before killing the animals were fasted (adults for $24 \mathrm{hr}$ and young for $12 \mathrm{hr}$ ) to observe the same conditions as during the measurement of the basal metabolic rate. Immediately after killing the liver, spleen, kidney, $m$. biceps femoris, heart and diaphragm were excised and placed in the Krebs III solution cooled to $+4^{\circ} \mathrm{C}$. The slices from the liver, spleen, kidney and heart were prepared freehand by using two parallely set safety razor blades (the method of Terry \& $\mathrm{M}$ a r t i n, after Fie ld, 1948). In principle it was attempted to obtain 
slices not thicker than $0.5 \mathrm{~mm}$ but in the case of adult rats some material was cut more coarsely in order to determine the relationship between the oxygen consumption and slice thickness.

From the prepared diaphragm some fat, connective tissue membranes and the central part were removed. The remaining part was sliced by cutting in parallel to the axis of muscle fibres in order to reduce their damage. The thickness of slices depended on the diaphragm thickness and on the average was equal to $0.37 \mathrm{~mm}$ in young rats, $0.74 \mathrm{~mm}$ in adult rats, $0.79 \mathrm{~mm}$ in young rabbits and $1.26 \mathrm{~mm}$ in adult rabbits.

By using a scalpel and a needle small fragments of tissue were prepared from the $m$. biceps femoris. Their mean thickness amounted to $0.71 \mathrm{~mm}$ in young rats, $1.52 \mathrm{~mm}$ in adult rats, $0.95 \mathrm{~mm}$ in young rabbits and $1.17 \mathrm{~mm}$ in adult rabbits.

Table 2.

Composition of incubation medium.

\begin{tabular}{|c|c|c|}
\hline 1. $0.90 \% \mathrm{NaCl}$ & 95 & parts \\
\hline 2. $1.15 \% \mathrm{KCl}$ & 4 & $"$ \\
\hline 3. $1.22 \% \mathrm{CaCl}_{2}$ & 3 & , \\
\hline 4. $2.11 \% \quad \mathrm{KH}_{2} \mathrm{PO}_{4}$ & 1 & , \\
\hline 5. $3.84 \% \mathrm{MgSO}_{4}$ & 1 & , \\
\hline 6. $1.30 \% \mathrm{NaHCO}_{3}$ & 3 & , \\
\hline 7. $0.10 \mathrm{M} \mathrm{Na-phosphate} \mathrm{buffer,} \mathrm{pH} 7.4$ & 3 & , \\
\hline 8. $0.16 \mathrm{M} \mathrm{Na-pyruvate}$ & 4 & , \\
\hline 9. $0.10 \mathrm{M} \mathrm{Na}$-fumarate & 7 & 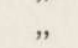 \\
\hline 10. $0.16 \mathrm{M} \mathrm{Na-L-glutamate}$ & 4 & $"$ \\
\hline 11. $0.30 \mathrm{M}$ glucose & 5 & $"$ \\
\hline
\end{tabular}

All the operations associated with preparing of slices were carried out in a cold room at $+5^{\circ} \mathrm{C}$. The oxygen consumption was measured by the direct method ( $\mathrm{U} \mathrm{m} \mathrm{bre} \mathrm{it} \mathrm{et} \mathrm{al.,} \mathrm{1957)} \mathrm{using} \mathrm{the} \mathrm{Warburg} \mathrm{microrespiro-}$ meter (type V 85, B. Braun, Melsungen, German Federal Republic). The flasks of $13-17 \mathrm{ml}$ of volume contained in the main compartment $2 \mathrm{ml}$ of the incubation medium and in the central well $0.15 \mathrm{ml} 10 \% \mathrm{KOH}$. The remaining space was filled with pure oxygen which was passed for 5 min during $15 \mathrm{~min}$ thermal equilibration of the system. The time which elapsed from the moment of killing of the animal to the start of measurements did not exceed 30 to $40 \mathrm{~min}$. The oxygen consumption within first hour of incubation was assumed as a basis of calculations. The wet weight of the tissue was determined immediately after incubation by using a torsion balance while the dry mass was estimated on the analytical balance after drying the slices for $2.5 \mathrm{hr}$ in $105^{\circ} \mathrm{C}$. The incubation was carried out in the Krebs III medium at pH 7.4 and its 
composition is given in Table 2. On the whole 534 measurements of the oxygen consumption by tissues were carried out.

In parallel to determinations of oxygen uptake by tissues the depth of penetration of the tetrazolium salt (INT) was studied. The slices used for this purpose were 1 to $5 \mathrm{~mm}$ thick. The composition of the incubation medium was slightly different than that given in Table 2. The concentration of $\mathrm{NaCl}$ solution was equal to $1.8 \%$ and components $8-11$ were completely lacking and replaced by 5 volumes of $0.5 \%$ INT solution. The gas phase consisted of nitrogen but apart from this fact the incubation was carried out under similar conditions as for the determination of oxygen consumption. After incubation the slices were immersed into $10 \%$ formaldehyde, then embedded in $25 \%$ gelatin and cut into $20 \mu$ thick sections on a freezing microtome or on a cryostat. The depth of INT penetration was determined by means of a filar micrometer eye-piece after magnification 80 times. The mean value of INT penetration into particular tissues was computed from 40 estimations.

\section{RESULTS}

The oxygen consumption by slices of particular tissues was express ed in $\mathrm{ml} \mathrm{O}_{2} / \mathrm{g}$ fresh tissue/hr, or as $Q_{2}$, that is in $\mathrm{mm}^{3} / \mathrm{mg}$ dry mass $/ \mathrm{hr}$. The following bases of calculations were adopted: 1 . Total weight of the

Table 3.

Penetration of INT into the tissue slices, combined depth from both sides in $\mathrm{mm}$.

\begin{tabular}{|l|c|c|c|c|}
\hline \multicolumn{1}{|c|}{ Organ } & I $\begin{array}{c}\text { young } \\
\text { rats }\end{array}$ & II $\begin{array}{c}\text { adult } \\
\text { rats }\end{array}$ & III $\begin{array}{l}\text { young } \\
\text { rabbiis }\end{array}$ & IV $\begin{array}{l}\text { adult } \\
\text { rabbits }\end{array}$ \\
\hline Liver & $0.323 \pm 0016$ & $0.375 \pm 0.009$ & $0.252 \pm 0.012$ & $0.225 \pm 0.011$ \\
Spleen & $0.244 \pm 0.013$ & $0.408 \pm 0.018$ & $0.213 \pm 0.010$ & $0.423 \pm 0.050$ \\
Kidney & $0.514 \pm 0.024$ & $0.434 \pm 0.016$ & $0.542 \pm 0.025$ & $0.503 \pm 0.050$ \\
Muscle *) & $0.579 \pm 0.040$ & $0.997 \pm 0.033$ & $0.624 \pm 0.032$ & $0.952 \pm 0.067$ \\
Heart & $0.386 \pm 0.029$ & $0.571 \pm 0.020$ & $0335 \pm 0.013$ & $0.452 \pm 0.028$ \\
Diaphragm & $0.824 \pm 0.0 \varepsilon 9$ & $0.564 \pm 0.017$ & $0.452 \pm 0.034$ & $0.798 \pm 0.042$ \\
\hline
\end{tabular}

*) Muscle biceps femoris

slice; 2. weight of this part of the slice which participated in the metabolism as estimated from the Warburg formula; 3. weight of this part of the slice which participated in the metabolism as estimated from INT penetration. The depth of this salt penetration in individual tissues is given in Table 3.

The ratio of $\mathrm{QO}_{2}$ calculated on these three ways to the thickness of the liver slices from adult rats is presented in Fig. 1. When the total 
weight or the weight corrected according to the Warburg formula were used as the basis for calculations the $\mathrm{QO}_{2}$ value distinctly decreased with the increasing slice thickness (Fig. 1A \& B). This relationship disappeared after employing in the calculations the weight corrected according to the INT penetration (Fig. 1C). A similar phenomenon was also observed with the liver tissue from other animal groups although it was not so striking since the variations in the slice thickness were less

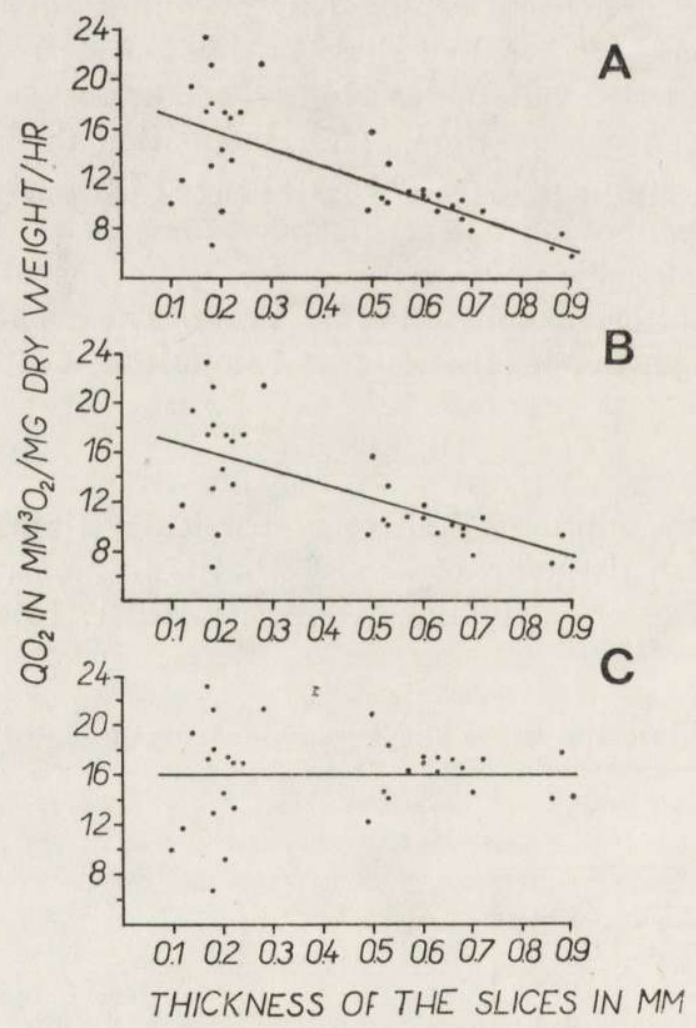

Fig. 1. Relationship between $\mathrm{O}_{2}$ consumption by the liver slices of adult rats and the slice thickness.

A - values calculated for total slice mass, B - values calculated for slice mass corrected by Warburg's formula, C - values calculated for slice mass corrected on the basis of penetration of INT.

marked than in the example presented in Fig. 1. The interdependence between the $\mathrm{QO}_{2}$ value and slice thickness was found in the spleen in all the animal groups except young rabbits. In the case kidney of the oxygen consumption computed per total weight of the slice markedly decreased with increase of their thickness but this effect disappeared after application of the correction calculated from the Warburg formula. 
The interdependence of $\mathrm{QO}_{2}$ and the thickness of slices from the heart muscle, $m$. biceps femoris, and diaphragm appeared only with extreme differences in the slice thickness, e. $g$. in the case of the diaphragm from adult rats and rabbits, and in the $m$. biceps femoris of adult rats.

The oxygen consumption by particular tissues of the studied animals is given in Table 4. Rows A in this Table contain the data calculated by the conventional method while the data of rows B are corrected according to the depth of INT penetration. The corrected data are higher in all cases, except the diaphragm of young rats, with the differences statistically significant $(P<0.05)$, or even highly significant $(P<0.01)$. Only in cases of the rat kidney (group I and II), muscles of adult rats (group II), the heart muscle of adult rats and rabbits (group II and IV), and the diaphragm of young rats (group I), the differences are not significant. The variance of the $\mathrm{QO}_{2}$ corrected results was in 34 cases (out of 48) smaller than the variance of results calculated by the conventional method.

The rate of oxygen utilization by individual tissues of the same animal often differed rather considerably. The lowest oxygen uptake was observed in slices of the $m$. biceps femoris in all animals groups. The spleen, liver and kidney belonged to the most active tissues. This order of metabolic activity was not preserved in all groups of animals, and moreover it could change in relation to the applied method of calculation, i.e. whether conventional or corrected results were used. The metabolic activity of the cardiac muscle and diaphragm was as a rule higher than that of the $m$. biceps femoris, but lower than of the remaining tissues. At the same time in most cases the oxygen consumption by the heart slices was more intensive than by the diaphragm. The data obtained with the heart slices should be treated with an exceptional care since the variance of results obtained for this tissue was so high that the calculated mean is not very reliable.

The relationship between the tissue oxygen consumption and the animals size depends on the type of tissue. The $\mathrm{QO}_{2}$ values obtained for the liver tissue and calculated by the standard method decreased with greater animal size. This was distinctly visible when the $\mathrm{QO}_{2}$ values of the liver from small and large animals of the same species were compared (differences highly significant). The comparison of the liver $\mathrm{QO}_{2}$ of adult rats and young rabbits, which showed rather similar body weight, was in spite of expectations highly significant. Also the corrected results did not improve this dependence and even disturbed it further. In rabbits the difference between $\mathrm{QO}_{2}$ of the liver from young or adult specimens is statistically not significant.

The most regular reduction of the $\mathrm{QO}_{2}$ value with the increased body 


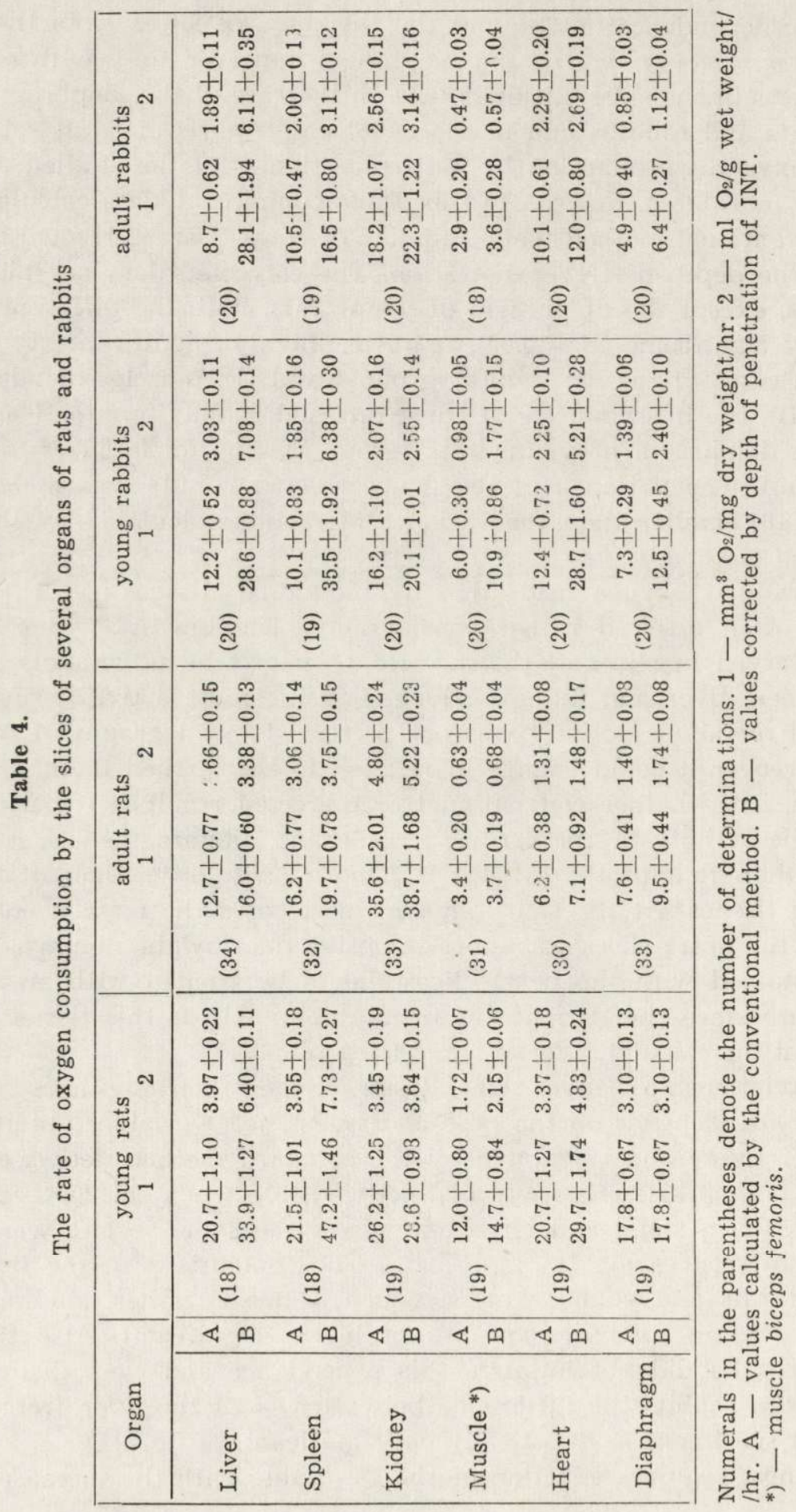


size was found for the spleen, both for the intra- and interspecies observations. At the same time the interdependence of $\mathrm{QO}_{2}$ and body size was more apparent in the case of corrected values. A certain drop of the $\mathrm{QO}_{2}$ value with the increased body size of the animals was noted also for the $m$. biceps femoris, the heart muscle and the diaphragm but the change was rather irregular. The oxygen utilization by slices of the adult rat kidney was much higher than that of the young rats $(\mathrm{P}<$ 0.01 ). The same trend was recorded for $\mathrm{QO}_{2}$ of the kidney from young and adult rabbits, but the difference was statistically not significant. On the other hand the differences between young rats and rabbits were highly significant $(\mathrm{P}<0.01)$ with higher $\mathrm{QO}_{2}$ values in the rat kidney slices.

\section{DISCUSSION}

The reduction of tissue $\mathrm{QO}_{2}$ observed with the increased slice thickness even after correction of the results according to the Warburg formula (Fig. 1B), confirms the conclusion drawn by $\mathrm{C}$ a s c a r a no et al. $(1959,1961,1964)$ that this formula does not suffice for an accurate estimation what part of the slice is engaged in the metabolism. The correction based on the penetration depth of tetrazolium salt (INT) cancels the relationship between the slice thickness and $Q \mathrm{O}_{2}$ value (Fig. 1C). This fact indicate that the described correction is very useful in metabolic studies of the isolated tissues, and moreover, that results of many authors computed for the whole mass of $0.5 \mathrm{~mm}$ thick slices are too low, especially in the case of such tissues as the liver and spleen. The total depth of INT penetration (from both sides of the slice) was in the liver at most $0.375 \mathrm{~mm}$ (Table 3 ), hence at least $1 / 4$ of the $0.5 \mathrm{~mm}$ thick slice did not participate in the measured metabolism. Slightly better pene-tration of INT was observed in the spleen slices and far better in the kidney and the cardiac muscle. The deepest penetration of tetrazolium salt occurred in tissues showing the lowest metabolism.

The depth of INT penetration into tissues was lower not only than the thickness of the prepared slices but also than the maximum thickness calculated from the Warburg formula. Thus it is clear that in these cases the corrected $\mathrm{QO}_{2}$ values significantly differed from the uncorrected ones. One might conclude that for tissue metabolic studies in vitro thinner slices, not exceeding $0.3 \mathrm{~mm}$, should be prepared. However, the preparation of such a thin slices is technically difficult. Moreover, thin slices contain rather high percentage of damaged cells and many authors observed that the impairment of the normal cell structure results in the reduction of tissue metabolic rate ( $\mathrm{Gr}$ e e $\mathrm{n}, 1938$; K le i- 
be $\mathrm{r}$ et al., 1943). The cellular damage may explain low $\mathrm{QO}_{2}$ values of several liver slices of $0.1-0.2 \mathrm{~mm}$ thick, as indicated by the position of some points in Fig. 1. Similarly low $\mathrm{QO}_{2}$ values were recorded among the thinnest slices from other tissues, especially from the diaphragm and $m$. biceps femoris. It appears then that in the studies of tissue metabolism in vitro slightly thicker slices $(0.5-1 \mathrm{~mm})$ are better, providing the correction based on the depth of INT penetration in control slices is applied. With such procedure the most credible data may be obtained.

The $\mathrm{QO}_{2}$ values of the rat tissue slices obtained in the present study by the standard Warburg technique are similar to those obtained by Huston \& M artin (1954) during incubation in the Krebs III solution and to those of Bertalanffy \& Pirozynski (1951) with incubation in the Krebs-Ringer solution. The comparison of the obtained results with those of other authors studying the metabolism of rat tissues in vitro is not possible because they employed incubation media markedly different in respect of the content of certain components. For the same reason it is impossible to compare the results obtained for the tissues of adult rabbits with those reported by $\mathrm{Krebs}$ (1950). This author incubated rabbit tissues only in the Krebs II solution. As for the metabolism of young rabbit tissues no relevant data in the available literature were found.

The comparison of the relationship between the tissue metabolic rate and body size of the studied animals with the relationship between the basal metabolism and body size is illustrated in Fig. 2. The part A of this Figure represents the intraspecies comparison of young and adult rats, part $\mathrm{B}$ - the interspecies comparison of adult rats and rabbits, while part C - the comparison of animals showing extreme differences in body size, i.e. young rats and adult rabbits. Since in the described experiments the basal metabolic rate was not measured, the informations on this rate were adopted from the literature (K le i b e r, 1961). According to these data, obtained from rather large material and by an accurate method, the basal metabolic rate of young rats (approximately $16 \mathrm{~g})$ amounts to $200 \mathrm{kcal} / \mathrm{kg} /$ day, that of adult rats $(210 \mathrm{~g})$ to $125 \mathrm{kcal} /$ $\mathrm{kg} / \mathrm{day}$, and adult rabbits (approximately $2400 \mathrm{~g}$ ) $44 \mathrm{kcal} / \mathrm{kg} /$ day.

The first columns in each part of Fig. 2 correspond to the basal metabolic rate of large animals expressed as percentage of this rate in small animals. Further columns show a similar comparison of the metabolic rate of individual tissues, calculated by the conventional method and with the application of the above described correction. If the effect of the animal body size on the tissue metabolic rate is the same as the effect on the basal metabolic rate, all the columns in the given part of 
the Figure should be equal. We can see, however, that the situation is different. The results obtained for young and adult rats, differing in body weight by approximately 13 times, are most compatible with the theoretical expectation. A decrease in the metabolic rate with increas-

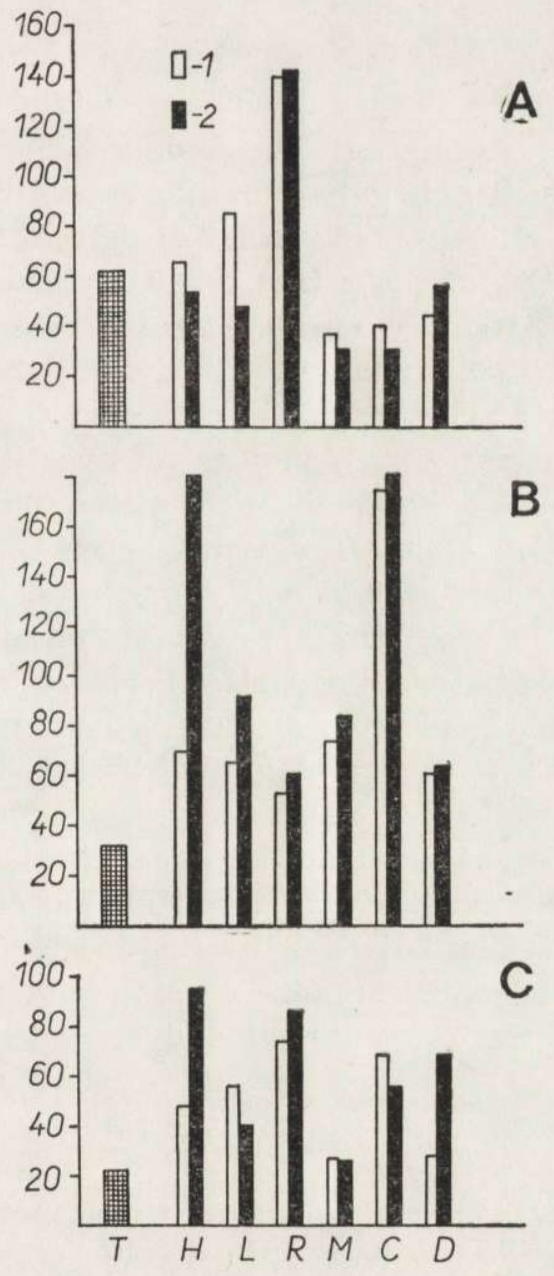

Fig. 2. Metabolic rate of large animals and their tissues expressed as percent of metabolic rate small animals and their tissues.

A - adult rat vs. baby rats, $\mathrm{B}$ - adult rabbit vs. adult rat, $\mathrm{C}$ - adult rabbit vs. young rat. $\mathrm{T}-$ total animals, $\mathrm{H}-$ liver, $\mathrm{L}-$ spleen, $\mathrm{R}-$ kidney, $\mathrm{M}-$ muscle (biceps femoris), $\mathrm{C}-$ heart, D - diaphragm. 1 - data calculated by conventional method, 2 - data corrected on the basis of penetration of INT.

ing body size was in this case even more pronounced than a drop of the basal metabolism, especially when the corrected $\mathrm{QO}_{2}$ values are considered. The kidney slices constituted the only exception in this rule $\mathrm{QO}_{2}$ of these slices derived from adult rats amounted to almost $140 \%$ 
of $\mathrm{QO}_{2}$ values of the young rat kidney. The observed increase of the kidney slices $\mathrm{QO}_{2}$ value during the rat ontogenesis is consistent with the results reported by Bertalanffy \& Pirozynski (1951).

The highest differences between the interdependence of the metabolic rate and body size, and of the basal metabolism and body size, were found after the comparison of the adult rats with adult rabbits (the difference in the body weight of approximately 11 times). The basal metabolism of adult rabbits constitutes only $32 \%$ of that of rats. The calculated conventional $\mathrm{QO}_{2}$ values of the rabbit liver, spleen, kidney, $m$. biceps femoris and diaphragm constituted from 54 to $64 \%$ of the rat tissues $Q_{2}$ values. $Q_{2}$ of the rabbit cardiac muscle amounted to $175 \%$ of the corresponding figure for rats. The difference between the interdependence of the metabolic rate and body size in the studies in vitro and in vivo is even higher when the corrected $\mathrm{QO}_{2}$ values are adopted as a basis for the comparison. In the case of liver slices the employment of the corrected values leads to the reversal of the negative correlation between $\mathrm{QO}_{2}$ and body size into the positive one.

When comparing adult rabbits and young rats, i.e. animals showing extreme differences in body size (approximately 150 times), the relationship between tissue $\mathrm{QO}_{2}$ and body size is more similar to the interdependence of the basal metabolism and body size than in the case of adult animals of these species. All the studied tissues derived from large animals consumed less oxygen than homologous tissues from small animals. The decrease of $\mathrm{QO}_{2}$ resulting from the increased body size is, however, considerably smaller than the reduction of the basal metabolic rate. This lack of parallel between the relationship of basal metabolism and $\mathrm{QO}_{2}$ from one side and body size from the other exists equally with the employment of the conventional and corrected $\mathrm{QO}_{2}$ values. Moreover, the corrected $\mathrm{QO}_{2}$ values for three tissues (liver, kidney, diaphragm) bring about the reduction in the similarity between the metabolism in vitro and in vivo.

On the basis of similarity between the tissue metabolism in vitro and the basal metabolism of intact animals Weymouth et al. (1942), $\mathrm{Schmidt}-\mathrm{N}$ ielsen (1951), and Fuhrman et al. (1961) concluded that the metabolic rate of the animal organism and its characteristic dependence on the body size are conditioned by the inherited factors associated with cells alone. This idea was also supported, though less resolutely, by $\mathrm{Krebs}(1950)$. Hence these authors, in the contrary to Terroine \& Roche (1925) and Grafe (1925), suggest that the tissue metabolism is independent from the central regulating systems of the animal organism. The reported by these authors similarity between the metabolism in vivo and in vitro, though quite considerable, 
was far from total parallelism. More accurate measurements of oxygen consumption by application of the appropriate correction in calculations in vivo resulted in most cases in the reduction of these values. Thus it appears, that the existing differences cannot be explained by technical errors committed by previous authors during estimations in vitro. One should consider again the origin of both similarities and differences. In the process of evolution cells of various animal species certainly become adapted to such level of metabolism owing to which the course of metabolic processes in the organism of small animals is faster than in larger ones. This fact may be responsible, for example, for some differences in the enzymes concentration in tissues of the animals which differs in body size (Rosenthal \& Drabkin, 1943; Kunkel \& C a mpbe11, 1952; Fried \& Tripton, 1953). Such cellular factors as the concentration of enzymes may determine, however, not the basal metabolic rate but only certain range in which metabolic rate can change. This range extends from a certain minimum (basal metabolism) to the maximum accompanying an intense, brief physical effort. Rates of tissues metabolism in situ vary within this range in relation to actual conditions of the animal. The perception of changes in these conditions certainly occurs by specialized receptors and not by individual tissues. The information is transmitted to tissues by the central regulating systems: nervous and humoral. According to Grafe (1925) the effect of these systems on the tissue metabolism in situ appears as an inhibition. However, there are premises indicating that in the case of the muscle tissue, the normal tonus of which depends on the constant flow of stimuli from the central nervous system, the discussed effect of the central regulating systems shows the effect of stimulation. The isolation of a tissue from the organism cuts it off from the regulating systems. A persisting partial similarity between the metabolism in vitro and in vivo may testify that in the surviving tissue, besides a certain concentration of enzymes and metabolites, the effect of the previously acting regulating systems is temporarily preserved. The force and the time of action of this effect may undergo serious modifications. It is impossible to specify what fraction of the previous effect of the central regulators remains in the isolated tissue, since this may depend on the type of the effect. In the case of the muscle tissue, the action of which is regulated mainly by the nervous system by means of acetylcholine, which gets quickly decomposed, the effect of the central regulator may disappear almost immediately after isolation of a muscle. The effect of certain hormonal factors, e.g. thyroxine, may probably persist much longer. The isolation of a tissue from the organism may hence alter conditions required for the normal course of metabolic processes by at 16 - Acta theriol. 
least partial abolition of the stimulatory or inhibitory effect of the central regulating systems. Due to this fact the state of individual surviving tissues may considerably differ from their state in situ. It is then not surprising that the interdependence of the metabolic rate of isolated tissues and the body size differs from the relationship of the body size and basal metabolism.

Terroine \& Roche (1925) and Grafe (1925) claimed that the homologous tissues of various animals show in vitro a similar intensity of respiration. As already mentioned the results of more recent publications did not confirm the validity of this conviction. Also Grafe's suppositions on the more intensive tissue metabolism in vitro were abandoned. The summated tissue metabolism in vitro was found to reach only 66 to $72.5 \%$ of the basal metabolism of studied animals (F i eld et al. 1939; M a r tin \& F u hrman, 1941; F u hrman et al., 1961). Only the results reported by Huston \& M a r tin (1954) obtained by a modified technique of measurements gave the sum of $101.8 \%$. The results of the present experiments, corrected according to the discussed principles, also contradict the conviction of $\mathrm{Ter}$ roine \& $\mathrm{R} \mathrm{oche} \mathrm{(1925),} \mathrm{that} \mathrm{in} \mathrm{vitro} \mathrm{the} \mathrm{tissue} \mathrm{metabolic} \mathrm{rate} \mathrm{is} \mathrm{identical} \mathrm{in}$ large and small animals. Since in the literature there are available some data on the weight of individual organs in the various size rats, it was possible to verify the second conviction of G r a f e (1925) on the more intensive tissue metabolism in vitro than in vivo. This examination was based on the calculations, the results of which are presented in Table 5 . The weight of studied organs constituted $49.86 \%$ of the body weight in young rats and $50.75 \%$ in adult rats. In the case of young rats the summated tissue metabolism calculated from the uncorrected values expressed as $\mathrm{ml} \mathrm{O}_{2} / \mathrm{g}$ fresh tissue amounts to $57 \%$ of the young rat basal metabolic rate, hence $7 \%$ more than it is expected from the percentage share of these organs in the total weight of the animal. When the corrected values were employed the obtained sum constituted as much as $75.8 \%$ of the basal metabolism, i.e. $26 \%$ more than the share of weight of the studied organs in the total animal weight. Certainly these organs belong to the most active metabolically but the oxygen consumption by some other tissues not studied here is also rather intensive. The uncorrected values were reported as 1.08 for the intestinal tract and 1.39 $\mathrm{ml} \mathrm{O}_{2} / \mathrm{g}$ fresh tissue/hr for the brain ( $\mathrm{H} \mathrm{u}$ s t o n \& $\mathrm{M}$ a r t i n, 1954), and 1.15 for the lungs, 0.362 for skin and $0.145 \mathrm{ml} \mathrm{O}_{2} / \mathrm{g}$ fresh tissue/hr for skeleton (F i e l d et al. 1939). The summated tissue metabolism of these tissues constitutes $9.10 \%$ of the basal metabolism while their weight amounts to $32.46 \%$ of the rat weight. The total weight of the organs studied in the present experiments and by other authors approaches 


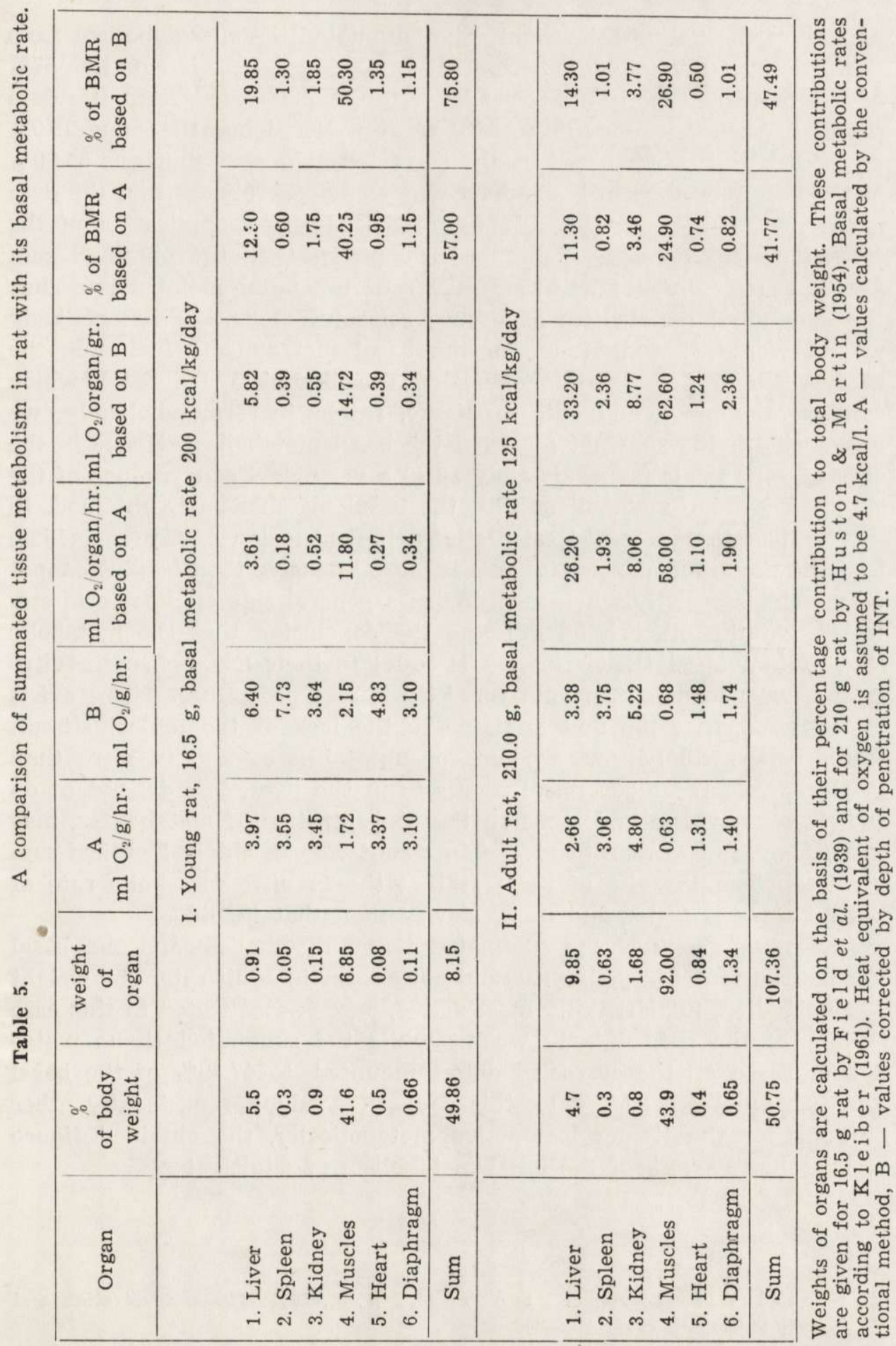


$82.32 \%$ of the young rat weight. The summated tissue metabolism from the present study calculated from the uncorrected data is equal to $57 \%$ of the basal metabolism. After adding $9.10 \%$ calculated from the data in the literature it amounts to $66.10 \%$. However, when the same $9.10 \%$ are added to the sum based on the corrected values, as much as $84.90 \%$ of the basal metabolism is obtained. Since one can suppose that the data given in the literature should be increased after application of the correction based on the depth of INT penetration, the obtained sum would be certainly higher than $9.10 \%$ of the basal metabolism. Thus the summated metabolism of tissues constituting $82.32 \%$ of the body weight would exceed $84.90 \%$ of the basal metabolism. Including the metabolism of the remaining part of the organism (ca 18\%), which contains the blood and adipose tissue, rather inert metabolically, we might obtain the sum not far from the basal metabolism. Hence in the case of young rats (approximately $16 \mathrm{~g}$ ) a very good convergence of the summated tissue metabolism with the basal metabolism is obtained. In the light of the presented calculations the conclusion of $\mathrm{Gr}$ a f e (1925) that the tissue metabolism in vitro is more intensive than in vivo cannot be upheld, especially when regarded as a general rule applicable to any tissue. On the other hand drawing the conclusion that the metabolic rate of individual tissues in situ is equal to their metabolism in vitro in the experiment carried out correctly is also premature. There exists a possibility that the muscle tissue to the lack of the tonical stimuli from the central nervous system consumes less oxygen in vitro than in situ, while the biochemical processes in the liver, less dependent on the nervous system and more on the concentration of metabolites, may run faster in vitro than in vivo. As a result we can obtain identical sum of metabolism in spite of the fact that the in vitro metabolic rate of some tissues is faster and other slower than that in vivo.

The convergence of the summated tissue metabolism and the basal metabolism found in young rats did not appear in adult rats. The weight of the studied, metabolically most active, organs constituted in this case $50.75 \%$ of the animal body weight while the summated tissue metabolism based on the corrected data amounted to $47.49 \%$ of the basal metabolism. After adding to this sum the values reported by other authors, for the tissues less active metabolically, the obtained figure reaches hardly $70 \%$ of the basal metabolism of adult rats.

\section{REFERENCES}

1. Bertalanffy L. von \& Pirozynski W. J., 1951: Tissue respiration and body size. Science, 113: 599-600. 
2. Bertalanffy L. von \& Pirozynski W. J., 1953: Tissue respiration, growth and basal metabolism. Biol. Bull. mar. biol. Lab. 105: 240-256.

3. Bertalanffy L. von \& Estwick R. R., 1953: Tissue respiration of musculature in relation to body size. Am. J. Physiol. 173: 58-60.

4. Cascarano J. \& $\mathrm{Zw}$ e if a ch B. W., 1959: In vitro studies of the metabolism of tissue slices. I. Metabolic and physical factors influencing the penetration of tetrazolium salts. J. biophys. biochem. Cytol. 6: 215-220.

5. Cascarano J. \& Z Z eif a ch B. W., 1961: Physical and metabolic factors * in diffusion of solutes into tissue slices. Am. J. Physiol. 200: 1285-1292.

6. Cascarano J., Rubin A. D., Chick W. L. \& Z weifach B. W., 1964: Metabolically induced permeability changes across mesothelium and endothelium. Am. J. Physiol, 206: 373-382.

7. Crandall R. R. \& Smith A. H., 1952: Tissue metabolism in growing birds. Proc. Soc. exp. Biol. Med., 79: 345-346.

8. Field J., 1948: Respiration of tissue slices. Meth. med. Res. 1: 289-294.

9. Field J., Belding H. S. \& M a r tin A. W., 1939: An analysis of relation between basal metabolism and summated tissue respiration in the rat. J. cell. comp. Physiol. 14: 143-157.

10. Fried G. H. \& Tripton S. R., 1953: Comparison of respiratory enzyme levels in tissue of mammals of different sizes. Proc. Soc. exp. Biol. Med. 82: $531-532$,

11. Fuhrman F. A., Fuhrman F. J., Farr D. A. \& Fail J. H., 1961: Relationship between tissue respiration and total metabolic rate in hypo- and normothermic rats. Am. J. Physiol. 201: 231-234.

12. Grafe E., 1925: Gewebsatmung. Med. Wochenschr. 51: 640-642.

13. Green D. E., 1938: Reconstruction of the chemical events in living cells. Perspective in Biochemistry. Cambridge University Press. 1-184. Cambridge.

14. Huston M. J. \& Martin A. W., 1954: Rate of respiration of tissues in contact with oxygen. Proc. Soc. exp. Biol. Med. 86: 103-107.

15. Kleiber M., 1941: Body size and metabolism of liver slices in vitro. Proc. Soc. exp. Biol. Med. 48: 419-423.

16. Kleiber M., 1947: Body size and metabolic rate. Physiol. Rev. 27: 511-541.

17. Kleiber M., 1961: The fire of life. John Wiley and Sons. 1-454. New York - London.

18. Kleiber M., Cole H. H. \& Smith A. H., 1943: Metabolic rate of rat fetuses in vitro. J. cell. comp. Physiol. 22: 170-173.

19. Krebs A. H., 1950: Body size and tissue respiration. Biochem. biophys. Acta 4: $249-269$

20. Kunkel H. O. \& Campbel1 E. J., Jr., 1952: Tissue oxidase activity and body weight. J. biol. Chem. 198: 229-236.

21. Martin A. W. \& Fuhrman F. A., 1941: The relation between basal metabolism and summated tissue respiration in the dog. Am. J. Physiol., 133: P. 379. .

22. Rosentha1 O. \& Drabkin D. L., 1943: The cytochrome content of normal and neoplastic mammalian epithelium, and its correlation with body mass. J. biol. Chem. 150: 131-141.

23. Schmidt-Nielsen K., 1951: Tissue respiration and body size. Science, 114: 306-307.

24. Terroine E. F. \& R o che J., 1925: Production calorique et respiration des tissus in vitro chez de homeotherms. C. r. hebd. Seanc. Acad. Sci. Paris, 180: 225-227. 
25. Umbreit W. W., Burris R. H. \& Staufner J. F., 1957: Manometric techniques. Burgess. Publ. Co. 1-338. Minneapolis, Minnesota.

26. We y mouth F. W., Field J. \& Kle ib e r M., 1942: Relation between body size and metabolism. Proc. Soc. exp. Biol. Med. 49: 367-370.

Received, April 5, 1969.

Polish Academy of Sciences,

Institute of Animal Physiology and Nutrition,

Jabłonna near Warsaw.

\section{Roman JUSIAK}

\section{METABOLIZM TKANEK A WIEK I ROZMIARY CIAEA SZCZUROW I KROLIKOW}

Streszczenie

Celem badań, wykonanych techniką Warburga, przy użyciu środowiska Krebsa III (Tab. 2), było ustalenie zależności między metabolizmem tkanek in vitro od wieku i rozmiarów ciała szczurów i królików (Tab. 1) oraz porównanie jej z zależnością między tempem przemiany podstawowej całych zwierząt a ich wiekjem i rozmiarami ciała. Zagadnienie to badano wielokrotnie lecz wyniki podawane przez poszczególnych autorów znacznie różnily się między sobą. Przyczyną różnic mogły być błędy popełniane przy badaniu metabolizmu tkanek standardową techniką Warburga. Dane z nowszej literatury i uzyskane w niniejszej pracy (Ryc. 1) świadczą bowiem, że przy tej technice tylko część masy badanych skrawków bierze udział $w$ metabolizmie, podczas gdy oznaczone pobieranie tlenu przelicza się na całą masę. W niniejszej pracy przyjęto za słuszny pogląd C a s c a r a n o i wsp., że użycie soli tetrazoliowej, zwanej w skrócie INT (chlorek 2-p-jodofenylo-3-p-nitrofenylo-5-fenylotetrazoliowy), pozwala oszacować jaka część skrawka tkanki bierze udział w metabolizmie (Tab. 3) i na tej podstawie skorygować otrzymane wyniki.

Mimo przeprowadzonej korekcji wyników (Tab. 4), zależność tempa metabolizmu izolowanych tkanek od rozmiarów ciała zwierząt (zarówno przy porównaniu wewnątrzgatunkowym, jak i międzygatunkowym) nie odzwierciedlała $w$ pelni zależności tempa przemiany podstawowej zwierząt od ich rozmiaru ciała. Wprawdzie metabolizm większości badanych tkanek ze zwierząt małych był intensywniejszy niż homologicznych tkanek ze zwierząt dużych, lecz nie o tyle, o ile różnila się przemiana podstawowa (Ryc. 2).

Skorygowane wartości pobierania tlenu przez tkanki były z reguły wyższe od obliczonych w sposób standardowy (Tab. 4) i od podawanych w literaturze. Oszacowana suma metabolizmu tkanek badanych w niniejszej pracy (Tab. 5), po dodaniu do niej, zaczerpniętych z literatury, wartości otrzymanych na pózostałych tkankach, wynosila około $100 \%$ przemiany podstawowej szczurów młodych, lecz zaledwie około $70 \%$ tej przemiany w przypadku szczurów dorosłych.

Otrzymane wyniki świadczą o tym, że metabolizm tkanek in vitro różni się znacznie od ich metabolizmu in vivo. Główną przyczyną tej różnicy, zdaniem autora, jest szybkie wygasanie wpływu centralnych systemów regulujących (nerwowego i humoralnego) na procesy metaboliczne zachodzące w komórkach izolowanych tkanek. 